\title{
Promoter polymorphisms in genes involved in porcine myogenesis influence their transcriptional activity
}

Silvia Bongiorni ${ }^{1 *}$, Francesca Tilesi ${ }^{2}$, Silvia Bicorgna ${ }^{1}$, Francesca lacoponi ${ }^{1}$, Daniela Willems ${ }^{2}$, Maria Gargani ${ }^{1}$, MariaSilvia D'Andrea ${ }^{3}$, Fabio Pilla ${ }^{3}$ and Alessio Valentini ${ }^{1}$

\begin{abstract}
Background: Success of meat production and selection for improvement of meat quality is among the primary aims in animal production. Meat quality traits are economically important in swine; however, the underlying genetic nature is very complex. Therefore, an improved pork production strongly depends on identifying and studying how genetic variations contribute to modulate gene expression. Promoters are key regions in gene modulation as they harbour several binding motifs to transcription regulatory factors. Therefore, polymorphisms in these regions are likely to deeply affect RNA levels and consequently protein synthesis. In this study, we report the identification of single nucleotide polymorphisms (SNPs) in promoter regions of candidate genes involved in development, cellular differentiation and muscle growth in Sus scrofa. We identified SNPs in the promoter regions of genes belonging to the Myogenic Regulatory Factors (MRF) gene family (the Myogenic Differentiation gene, MYOD1) and to Growth and Differentiation Factors (GDF) gene family (Myostatin gene, MSTN, GDF8), in Casertana and Large White breeds. The purpose of this study was to investigate if polymorphisms in the promoters could affect the transcriptional activity of these genes. With this aim, we evaluated in vitro the functional activity of the luciferase reporter gene luc2 activity, driven by two constructs carrying different promoter haplotypes.
\end{abstract}

Results: We tested the effects of the G302A (U12574) transition on the promoter efficiency in MYOD1 gene. We ascertained a difference in transcription efficiency for the two variants. A stronger activity of the A-carrying construct is more evident in C2C12. The luciferase expression driven by the MYOD1-A allelic variant displayed a 3.8-fold increased transcriptional activity. We investigated the activity of two haplotype variants (AY527152) in the promoter of GDF8 gene. The haploptype-1 (A435-A447-A879) up-regulated the expression of the reporter gene by a two-fold increase, and hence presumably of the GDF8 gene, in both $\mathrm{CHO}$ and $\mathrm{C} 2 \mathrm{C} 12$ cultured cells.

Conclusions: In vitro the MYOD1-A allelic variant could up-regulate the expression of MYOD1 gene. Additionally, we could assess a different response of in vitro gene expression according to cell type used to transfect constructs, suggesting that MyoD activation is regulated by mechanisms that are specific of myoblasts.

Keywords: GDF8 gene, MYOD1 gene, Myogenesis, Promoter, Transcriptional activity, Sus scrofa

\footnotetext{
* Correspondence: bongiorni@unitus.it

${ }^{1}$ Department for Innovation in Biological, Agro-food and Forest systems, University of Tuscia, Viterbo 01100 , Italy

Full list of author information is available at the end of the article
} 


\section{Background}

Meat quality traits are economically important in swine; however, the underlying genetic control is very complex. For this reason, an improved pork production strongly depends on identifying and studying how genetic variations contribute to modulate gene expression. There is a consistent literature dealing with SNPs affecting coding regions, where the assessment of the possible effect of variation is quite straightforward. However, SNPs within control regions (both at $5^{\prime}$ and $3^{\prime}$ ) are scarcely studied, although their effect on phenotype might be dramatic. Promoters located upstream genes may extend several bases and initiate transcription. They are key regions in gene expression as they harbour several motifs binding to transcription regulatory factors. Therefore, polymorphisms in these regions are likely to deeply affect RNA amount and consequently protein synthesis. Genes which regulate proliferation and differentiation of precursor cells (myoblasts) into multinucleated myofibers and the consequent formation of muscle tissue (myogenesis), appear likely targets for meat quality determination.

The $M Y O D$ gene family consists of four structurally related genes: MYOD1, MYOG, MYF5, and MYF6. The expression of each $M Y O D$ gene takes place exclusively in skeletal muscles and their products are specific transcription factors which participate in muscle development [1-3]. In particular, products of MYOD1 and MYF5 genes are transcription factors that control the processes of myogenesis [3]. Each MYOD gene shows a specific pattern during myogenesis: MYOD1 regulates the embryonic process of mammalian myofiber formation and acts during terminal differentiation of muscle cells activating myogenin [4]. Moreover, phenotypic variations caused by MYOD1 mutations implicate myofiber-type transformation and myofiber hypertrophy $[5,6]$. Consequently, polymorphisms within MYOD1 gene could influence muscle fibers and meat production and quality [1]. Soumillion [7] and then Urbański [8] mapped the porcine MYOD1 on chromosomes 2. Polymorphisms within porcine MYOD1 have been reported by several groups [3,8,9]. Recently, three SNPs within the porcine MYOD1 gene in a population of Yorkshire and Berkshire pigs were found significantly associated with meat quality traits, lean meat production and several muscle fiber characteristics such as loin eye area and lightness [10].

The Myostatin gene (MSTN, GDF8) belongs to the Growth and Differentiation Factors $(G D F)$ gene family and negatively regulates skeletal muscle mass development [11]. The GDF8 gene is expressed during skeletal muscle development both at prenatal and postnatal stages $[12,13]$. Several studies have verified that mutations in GDF8 gene cause Double Muscled (DM) phenotype in various cattle breeds [13-16], in sheep [17], in mice [18], in $\operatorname{dog}$ [19] and in human [20,21]. Also mutations in cattle
GDF8 promoter affect the muscle conformation [22]. The DM phenotype is characterized by a visible and generalized increase in muscle mass due primarily to hyperplasia [23], an increase in number of cells caused by an excessive proliferation. This muscle condition is opposite to hypertrophy, where cells increase in size and not in number. A polymorphism, located at position 447 (A447G) of the porcine GDF8 promoter, occurs at a very high rate in the heavily muscled Belgian Piétrain breed. This mutation changes the $\mathrm{G}$ nucleotide at position 8 site into an $\mathrm{A} \mathrm{nu}$ cleotide disrupting a putative myocyte enhancer factor 3 binding site [24]. Moreover, it triggers a significantly higher MSTN expression in Longissimus dorsi of animals that were heterozygous (447AG) for the mutation compared with homozygous wild-type (447AA) and homozygous mutant (447GG) animals [24]. A differential expression of the porcine GDF8 gene was observed in younger animals. 4 weeks old piglets that were heterozygous (447AG) showed a lower MSTN expression than piglets that were homozygous wildtype (447AA). The differentiation of the tertiary myofibres starts at an age of about 4 weeks; at this stage, a lower expression of GDF8 gene could be correlated with an higher rate of differentiation, resulting in higher muscularity of Piétrain pigs [24].

Gene expression analysis of promoter showed that this mutation can modulate expression levels of the MSTN gene in Longissimus dorsi skeletal muscle [25]. In commercial lines of pigs, Guimaraes et al. [25] investigated allele frequencies of two SNPs (G435A and A447G), previously identified by Stinckens et al. [26] in the promoter region of the Myostatin gene, in complete Linkage Disequilibrium. They analysed MSTN gene expression pattern in the Longissimus dorsi skeletal muscle and performed a statistical association with body composition, carcass composition and meat quality traits. These SNPs were associated to growth and meat quality traits, even though they were not significantly associated with the expression levels of MSTN mRNA in muscle. In another study, these two polymorphisms seem to affected growth in Duroc pigs too [27].

In this study, we have chosen known SNPs in the promoter regions of genes involved in development, cellular differentiation and muscle growth, such as the G302A transition [3] in MYOD1 gene and three polymorphisms, G435A, A447G and T879A, [26] in GDF8 gene. We investigated if these polymorphisms in the promoter could affect the transcriptional activity of those genes. With this aim, we evaluated in vitro the functional activity of reporter gene activity, driven by two constructs carrying different promoter haplotypes, in two different types of cell cultures (epithelial $\mathrm{CHO}$ and myoblast $\mathrm{C} 2 \mathrm{C} 12$ cultured cells) to check if transcription factors are specific of the type of cell. 


\section{Methods}

\section{Pig samples and DNA extraction}

The Casertana breed is a very ancient Italian autochthonous pig breed reared in Campania, a region of Southern Italy. Large White breed originated in Yorkshire (United Kingdom) and is one of the major pig breeds raised for food all over the world. Casertana and Large White piglets of the same age were reared outdoors in the same environment and fed twice per day with the same commercial diet, following which their productive traits were recorded. Liver tissue was collected at 11 months of age at the time of slaughter. Samples were immediately stored in RNA later until analysis. Animal handling followed the European Union recommendation directive 2010/63/EU and the Italian low 116/92 about animal care. Genomic DNA was extracted from the liver of 19 animals, using Promega Wizard DNA Extraction Kit (Promega Corporation, Madison, Wi, USA) according to manufacturer's instructions, from liver tissue collected at slaughtering and stored at $-20^{\circ} \mathrm{C}$. DNA was checked for quality on agarose gel and quantified using a DTX microplate reader (Beckman Coulter) after staining with Picogreen (Invitrogen, Carlsbad, CA, USA).

\section{Sequencing analysis and SNP detection}

Primer pairs for candidate genes were designed from sequences available at NCBI, using primer3 software http:// fokker.wi.mit.edu/primer3 and synthesized by SigmaAldrich (Sigma, St. Louis, Mo, USA). The primer sequences, amplicon sizes and positions are reported in Table 1. To sequence PCR fragments and identify new SNPs, the High Fidelity PCR system (Roche, Diagnostic $\mathrm{GmbH}$, Mannheim, Germany) was used following standard conditions by Roche (Buffer 1x, dNTP mix $20 \mu \mathrm{M}$, Primer Forward $0.4 \mu \mathrm{M}$, Primer Reverse $0.4 \mu \mathrm{M}, 1 \mu \mathrm{g}$ DNA template, water to volume). A 5 min denaturation step was followed by 34 cycles of denaturation at $94^{\circ} \mathrm{C}(30 \mathrm{sec})$, annealing for $30 \mathrm{sec}$ and extension at $72^{\circ} \mathrm{C}(1 \mathrm{~min})$; the final extension step was carried out at $72^{\circ} \mathrm{C}$ for 5 minutes.

PCR products were purified using ExoSap-IT (USB Corporation, Affymetrix) to remove residual primers and dNTPs and used as templates for forward and reverse sequencing reactions. Sequencing was performed using a
CEQ8800 sequencer using DTCS QuickStart Kit and purifying with AgencourtCleanSEQ 96 (Beckman Coulter), according to manufacturer instructions. Sequencing of purified PCR products were also outsourced to Macrogen Inc. (www.macrogen.com) for double checking. Sequence analysis and alignments were performed using BLAST; http:/(www.ncbi.nlm.nih.gov/BLAST) and BioEdit softwares. A total of 19 animals were sequenced, namely, 10 Casertana and 9 Large White pigs.

\section{Cloning of allelic variants into a T/A vector and transformation into competent cells}

Fragments harbouring both copies of the target SNPs were cloned using Topo T/A Cloning ${ }^{\oplus}$ in order to separate the two allelic variants (Invitrogen). The T/A cloning and transformation into competent cells (JM109) were performed according to manufacturer's instructions (Invitrogen).

Plasmid constructs were transformed in JM109 competent cells. We mixed $0.5 \mu \mathrm{l}$ of plasmid in one vial of competent cells. After heat shock step $\left(0^{\circ} \mathrm{C}\right.$ for $20 \mathrm{~min}$, $42^{\circ} \mathrm{C}$ for $30 \mathrm{~min}$ ), we added $250 \mu \mathrm{l}$ of $\mathrm{LB}$ and incubate at $37^{\circ} \mathrm{C}$ for $1 \mathrm{~h}$. After spinning ( $3 \mathrm{~min}$ at $500 \mathrm{rpm}$ ), each vial was put down two LB plate with XGAL, IPTG and Amp and incubate overnight at $37^{\circ} \mathrm{C}$. Plasmid minipreparations, for colony screening and transfections, were performed with the PureYield ${ }^{\mathrm{mi}}$ Plasmid Miniprep System (Promega).

\section{pGL4.17 constructs}

We used the pGL4.17[luc2/Neo] vector (Promega), a basic vector with no promoter which encodes the luciferase reporter gene luc2 (Photinus pyralis) as reporter gene and is designed for high expression and reduced anomalous transcription. We inserted the MYOD1 and GDF8 amplicons carrying each allelic variants of promoter region, upstream to $l u c 2$ in pGL4.17 vectors. The primer sequences, amplicon sizes of the promoter upstream the coding region are reported in Table 2. The luciferase reporter gene luc2 (Photinus pyralis) was joined to the promoter sequences with matched reading frames. Constructs have been produced by Bio-Fab research (www.biofabresearch.it) and by GeneCust (www.genecust.com).

Table 1 The primer forward and reverse sequences, amplicon sizes and gene positions

\begin{tabular}{|c|c|c|c|c|c|c|c|}
\hline Gene & $\begin{array}{l}\text { SNP } \\
\text { position }\end{array}$ & $\begin{array}{l}\text { Accession } \\
\text { number/locus }\end{array}$ & Forward sequence & Reverse sequence & $\begin{array}{l}\text { Amplicon } \\
\text { size (bp) }\end{array}$ & $\begin{array}{l}\text { Gene } \\
\text { position }\end{array}$ & Reference \\
\hline & G302A & & & & & promoter & \\
\hline \multirow[t]{3}{*}{ MYOD1 } & C489T & U12574 & CCCGTCAGTCAGGAGGGACAG & CTTGGGCAGCCGCTGATTCG & 612 & 1st exon & Urbański and Kurył 2004 [3] \\
\hline & G566C & & & & & 1st exon & \\
\hline & G435A & & & & & promoter & \\
\hline \multirow[t]{2}{*}{ GDF8 } & A447G & AY527152 & GCCCTCTGGTCAAATGAGAA & TITCCTTTGCTCGCTGTT & 1234 & promoter & Stinckens et al. 2005 [26] \\
\hline & A879T & & & & & promoter & \\
\hline
\end{tabular}


Table 2 The primer forward and reverse sequences, amplicon sizes of promoter upstream the coding region

\begin{tabular}{llllll}
\hline Gene & SNP position & accession number/locus & forward sequence & reverse sequence & amplicon size (bp) \\
\hline MYOD1 & G302A & U12574 & TAGGCTACTACGGG & ATCCCAGCGGGGGCGG & 257 \\
GDF8 & A447G-A879T & AY527152 & GCCCTCTGGTCAAATGAGAA & GATTTAAAATCAATAC & 1139 \\
\hline
\end{tabular}

\section{Cell lines and in vitro transfection}

A Chinese Hamster Ovary $(\mathrm{CHO})$ cell line and a murine myoblast $(\mathrm{C} 2 \mathrm{C} 12)$ cell line (both from American Type Culture Collection, Rockville, MD, USA) were used to test the SNP effects in promoter regions. $\mathrm{CHO}$ and C2C12 cells were cultured by standard laboratory techniques in Dulbecco's Modified Eagle Medium (Lonza, Lonza Group Ltd, Basel, Switzerland) supplemented with $10 \%$ fetal bovine serum (FBS) (Cambrex, Bio Science, Walkesville, Md, USA) and 1\% l-glutamine (Sigma), only in $\mathrm{CHO}$ medium were added $1 \% \mathrm{MEM}$, non-essential amino acids (Sigma). Both cell cultures were maintained in a humidified atmosphere of $5 \% \mathrm{CO}_{2}$ at $37^{\circ} \mathrm{C}$. The day before transfection $\mathrm{CHO}$ and $\mathrm{C} 2 \mathrm{C} 12$ cells were plated in 24 multi-wells at a density of $9 \times 10^{4}$ and $7 \times 10^{4}$ cells per well, respectively. The day after cells were co-transfected by using Lipofectamine 2000 (Invitrogen), with two different plasmid constructs: the experimental reporter plasmid (pGL4.17[luc2/Neo]) and a co-reporter vector, pGL4.74[hRluc/TK] vector (Promega) which contains the $h R l u c$ reporter gene downstream a constitutive HSVTK immediate-early enhancer/promoter, to normalize the transfection process. The luciferase experimental reporter plasmid (pGL4.17[luc2/Neo]) is associated with the effect of each allelic variant (see pGL4.17 constructs), while the activity of the renilla co-transfected reporter vector (pGL4.74[hRluc/TK]) provides an internal control to assess transfection efficiency. Briefly, $0.25 \mu \mathrm{g}$ of plamids (ratio pGL4.17/pGL4.74 up to 20:1) and $1.6 \mu \mathrm{l}$ of Lipofectamine 2000 were mixed in $100 \mu \mathrm{l}$ of FBS-free Opti-MEM medium (GIBCO Invitrogen Corporation, Carlsbad, CA, USA) for $20 \mathrm{~min}$ and then added to each well containing cells. The cell-plate was then incubated at $37^{\circ} \mathrm{C}$ for $24 \mathrm{~h}$ and each well analyzed for firefly and renilla luciferase activities by bioluminescence analysis.

\section{Bioluminescence analysis}

Basically, a reporter assay is a method to translate a biomolecular effect, for example the functional activity of a promoter, into an observable parameter, such as photon production obtained through luminescence. Therefore, the functional activity of promoter variants was analysed in vitro with the Dual-Luciferase Reporter Assay System $^{\mathrm{Tm}}$ (DLR, Promega). In the DLR ${ }^{\mathrm{Tm}}$ Assay System, the activities of firefly (Photinus pyralis) and Renilla (Renilla reniformis) luciferases were measured sequentially on the same sample, in accordance with the manufacturer's protocol, by using TD-20/20 Luminometer (Promega) and were expressed as relative luminescence units (RLU) per well.

\section{Transfection design experiment}

The transfection experimental protocol was designed to assure reproducibility. To this aim, transfection experiments were performed in triplicate and repeated two times by using two mixes (mix A and mix B). Two independent experiments were performed in different days. In order that, each data point is the average of 12 replicates (Additional file 1: Table S1, Additional file 2: Table S2, Additional file 3: Table S3 and Additional file 4: Table S4). The ratio of Firefly to Renilla (FF/R) was taken to represent the normalized firefly luciferase activity. Data are expressed as mean and standard deviation (SD). Negative controls were included.

\section{Statistical analysis}

The in vitro association between haplotype and transcription efficiency was carried out using $\mathrm{y}=$ luciferase/ renilla ratio as dependent variable in the model $y=\mu+$ $\exp +\mathrm{d}+\mathrm{m}+\mathrm{r}+\varepsilon$, where $\mu$ is the overall mean, $d$ the day of the experiment (exp), $m$ the mix (A or B), $r$ the replicate ( 3 for each mix) and $\varepsilon$ the residual error. A p value $<0.05$ (two-tailed) was considered statistically significant. All analyses were performed by R-software version 2.15.1 (http://www.r-project.org/).

\section{Results and discussion}

In this study, we have chosen known single nucleotide polymorphisms in the promoter regions of genes involved in development, cellular differentiation and muscle growth; and we investigated if in these SNPs could affect the transcriptional activity of those genes. In order to exclude the complex interactions among genes, we assessed the effects of SNPs in an in vitro environment, consisting of only the promoter harbouring one SNP allele and a reporter gene. We analysed the expression levels using an in vitro assay, in two different types of cell cultures: a Chinese Hamster Ovary $(\mathrm{CHO})$ cell line and a murine myoblast $(\mathrm{C} 2 \mathrm{C} 12)$ cell line. The epithelial $\mathrm{CHO}$ cells derived from the ovary of the Chinese hamster and are the most commonly used mammalian cultured cells in studies of genetics and medical research. The $\mathrm{C} 2 \mathrm{C} 12$ cells are a primary line of murine myoblasts whose behavior corresponds to that of progenitor lineage. That's why the $\mathrm{C} 2 \mathrm{C} 12$ cells represent a simplified 
muscular tissue and have been used as a model for skeletal muscle development in several works [28].

\section{MYOD1 gene promoter analysis}

By sequencing the $5^{\prime}$ flanking region of the MYOD1 gene, Urbañski and Kury found a transition G302A [3] in the promoter region. In the region that we have analyzed (from 190n of U12574) in our samples, we have found the same polymorphism and no further ones. The functional activity of promoter variants was analysed in vitro with the Dual-Luciferase Reporter Assay System. The luciferase reporter gene luc2 (Photinus pyralis) was joined to the promoter sequences with matched reading frames (for details see paragraph pGL4.17 constructs in Methods). We monitored the quantitative expression of the reporter luciferase genes (luc2 and $h R l u c$ ) by luminescence assay (Additional file 1: Table S1 and Additional file 2: Table S2). Figures 1 and 2 show the luminescence results of the $\mathrm{G} 302 \mathrm{~A}$ variants in $\mathrm{CHO}$ cells and $\mathrm{C} 2 \mathrm{C} 12$ cells, respectively. The expression of the construct carrying the A allele, is higher in both cell systems, while it is statistically significant only in $\mathrm{C} 2 \mathrm{C} 12$. In the latter cells, ANOVA test showed a significant difference between the two variants, MYOD1-A and MYOD1-G (p < 0.001) therefore the A allele up-regulates the expression of $M Y O D 1$ gene in comparison with the $\mathrm{G}$ allele. In $\mathrm{C} 2 \mathrm{C} 12$ cultured cells, the luciferase expression driven by the MYOD1-A allelic variant displayed a 3.8 -fold increased transcriptional activity. However, the larger variability in $\mathrm{CHO}$ makes the difference between the two variants slightly over $(\mathrm{p}=$ $0.0541)$ the threshold we have chosen (0.05).

The stronger activity of the A carrying construct is more evident in $\mathrm{C} 2 \mathrm{C} 12$ cells which come from a myoblast line, cultured from the mouse thigh muscle and are competent to differentiate and to express characteristic muscle proteins. Instead, Chinese Hamster Ovary $(\mathrm{CHO})$ cell line derives from ovarian cells of the Chinese hamster. Therefore our data indicate that $M y o D$ activation

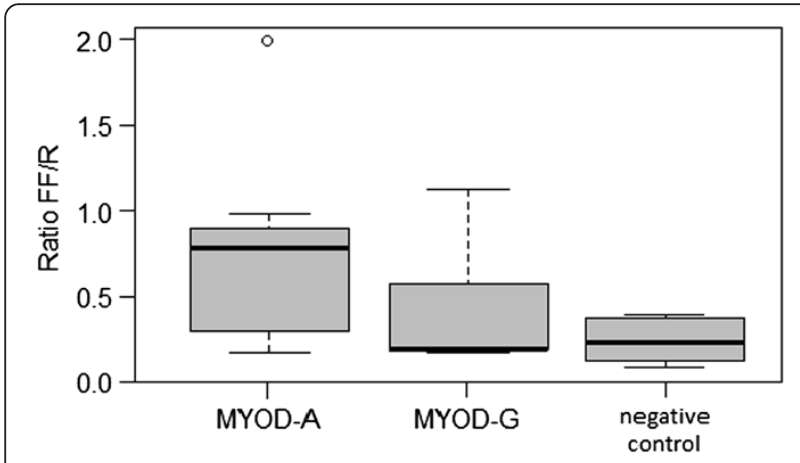

Figure 1 Box plot of the MYOD1 variant expression in $\mathrm{CHO}$ cells. The lines extending vertically from the boxes indicating variability outside the upper and lower quartiles. The outliers are plotted as circles.

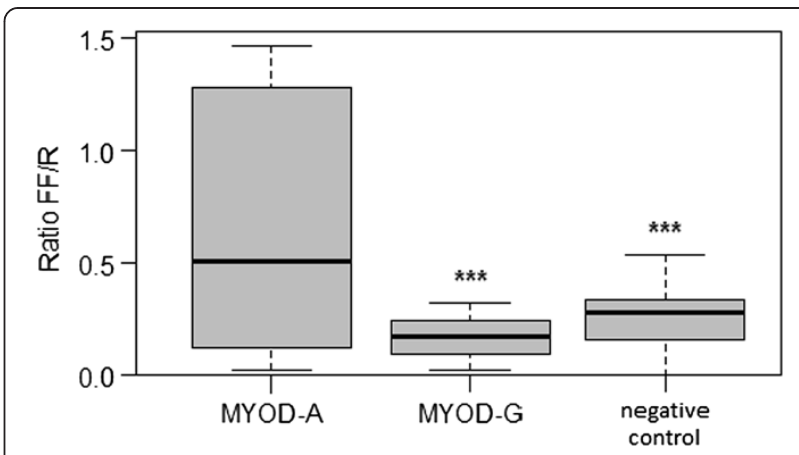

Figure 2 Box plot of the MYOD1 variant expression in $\mathrm{C} 2 \mathrm{C} 12$

cells. The lines extending vertically from the boxes indicating variability outside the upper and lower quartiles.

is regulated by mechanisms that are specific of myoblasts. MYOD1 shows a muscle-specific gene promoter sequence and transcription is regulated by tissue-specific transcription factors. Extensive studies have identified muscle-specific regulatory factors that drive myogenic differentiation [29]; however, the mechanisms underlying their expression are poorly understood. Several studies have shown the chromatin structure of the chromosomal MyoD core enhancer differs between myoblasts and other non-muscle cell types, suggesting epigenetic mechanisms involved in the $M y o D$ enhancer repression [30].

\section{GDF8 gene promoter analysis}

Previous studies have analysed porcine myostatin promoter and identified three polymorphisms: the T879A [31], the G435A and A447G [26]. In our samples we have found the same polymorphisms and no further ones. Additional file 3: Table S3 and Additional file 4: Table S4 show the luminescence results of two haplotype variants (haplotype-1: A435-A447-A879; haplotype-2: A435-G447-T879) in CHO cells and C2C12 cells, respectively. Figures 3 and 4 show the box plots of the GDF8 haplotype expression in $\mathrm{CHO}$ and $\mathrm{C} 2 \mathrm{C} 12$ cells, respectively. The haplotype-1 up-regulated the expression of the reporter gene by a two-fold increase in both cell systems. The ANOVA test showed that the expression differences between the two variants, haplotype-1 and haplotype-2, are highly significant $(\mathrm{p}<0.001)$ in both $\mathrm{CHO}$ and $\mathrm{C} 2 \mathrm{C} 12$ cultured cells.

These three SNPs were then associated with production traits [24,25,32,33]. Yu et al. [33] reported that these SNPs were associated with early growth traits in Yorkshire pigs; Guimaraes et al. [25] with growth and meat traits in two commercial pig populations (Duroc sires X synthetic white line dams). Stinckens et al. [24] reported a very high allele frequency of A447G in the Pietrain pig breed, for the SNP located at site 447 (A447G); while SNPs G435A and T879A were found to be associated with early growth 


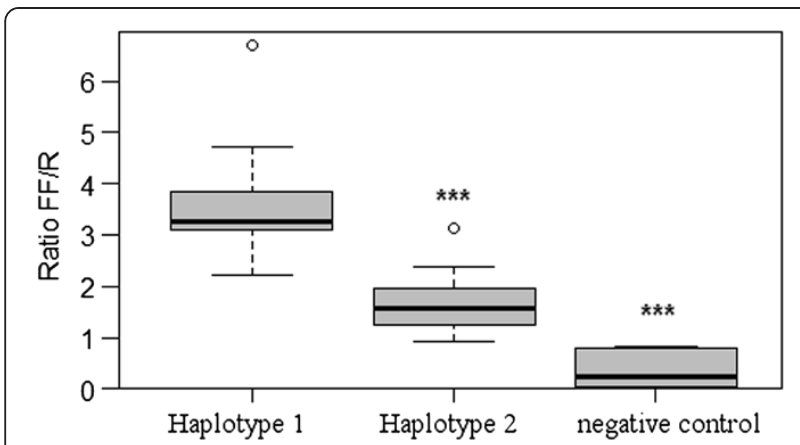

Figure 3 Box plot of the GDF8 variant expression in $\mathrm{CHO}$ cells. The lines extending vertically from the boxes indicating variability outside the upper and lower quartiles. The outliers are plotted as circles.

traits in Duroc pigs and strong linkage disequilibrium exists between them [24]. Liu et al. [34] analysed the associations of this haplotype with birth weight and early growth. A favourable effect on body weight was found for the allele carrying $\mathrm{G}^{435}-\mathrm{A}^{447}-\mathrm{T}^{879}$ [34]. The expression of porcine myostatin gene was investigated by qRT-PCR $[25,26]$ and by functional activity of reporter gene [34]. Liu and collaborators found a favourable effect on body weight to work of the allele carrying $\mathrm{A}^{447}$, and that the myostatin expression was different between breeds.

In the GDF8 A447G mutation, the $\mathrm{G}$ allele causes the disruption of a putative MEF3 binding site [24]. Several studies described an association of different GDF8 A447G genotypes with various carcass traits. In Stinckens' paper animals, at an age of 26 weeks, showed a significantly lower GDF8 expression in homozygous than heterozygous animals [24]; in contrast, in Guimaraes' work, a commercial synthetic line of pigs showed a reduced backfat thickness, a higher lean meat content and less marbling in heterozygous animals when compared with in homozygous wild-type and homozygous mutant animals [25].

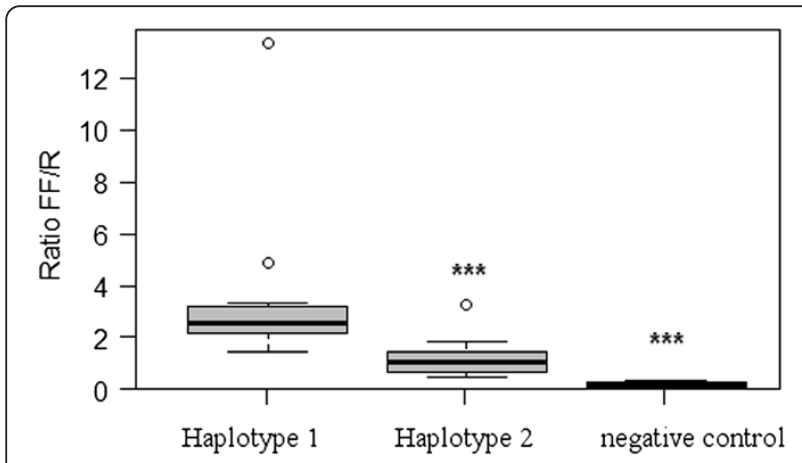

Figure 4 Box plot of the GDF8 variant expression in $\mathrm{C} 2 \mathrm{C} 12$ cells. The lines extending vertically from the boxes indicating variability outside the upper and lower quartiles. The outliers are plotted as circles.
We thus confirm that different haplotypes in the promoter region of GDF8 gene can modulate its expression. This behavior is shared in both kind of cells. Therefore, we hypothesize that GDF8 polymorphism interacts with transcription factors that are not muscle specific. Although the major role of myostatin is to suppress myoblast proliferation and myofiber hypertrophy, its function may not be confined to muscle tissue. Jiao et al. [35] detected porcine myostatin mRNA in non muscular tissues such as adipose tissue, heart, liver, spleen, lung kidney and cultured pig fibroblasts, although its expression varied among the different tissues. Myostatin expression has been detected in porcine pituitary gland [23], rat uterus [36], mouse mammary gland [37], adipose tissue [38] and tendons [39]. Myostatin has also been suggested to act as an autocrine factor in vivo [40]. Myostatin may play important roles in the development and maintenance of various tissues regulating the energy metabolism and fibrosis [35]. Guimaraes et al. [25] and Stinckens et al. [24] asserted there were only several muscle-related transcription factor binding sites in porcine MSTN promoter. Budasz-Swiderska et al. [41] showed that, during terminal differentiation of muscle, the TGF- $\beta 1$ may control MSTN-related regulation of myogenesis through the up-regulation of MSTN itself. Bing Deng et al. [42] found some adipogenesis- and myogenesis-related transcription factors binding sequence and that MSTN is up-regulated by MyoD and PPAR $\gamma$, but down-regulated by $C / E B P \alpha$ and $C / E B P \beta$ when cells were induced to differentiated into adipocytes.

\section{Conclusion}

The goal of this study was to test the effects of single nucleotide polymorphisms (SNPs) in the promoter regions of genes involved in development, cellular differentiation and muscle growth. We sequenced the promoter region of $M Y O D 1$ and GDF8 genes and we identified the G302A transition in the MYOD1 gene promoter and two haplotypes in GDF8 gene promoter. We evaluated in vitro the functional activity of reporter gene activity, driven by two constructs carrying different promoter haplotypes, for both genes. In this study, we confirmed that SNPs in the promoter region can modulate GDF8 gene expression in $\mathrm{C} 2 \mathrm{C} 12$ and $\mathrm{CHO}$ cells. Particularly, two haplotypes were investigated: haplotype-1 A435-A447-A879 and haplotype-2 A435-G447-T879. The haploptype-1 up-regulated the expression of the reporter gene by a two-fold increase, and hence presumably of the GDF8 gene, in both $\mathrm{CHO}$ and $\mathrm{C} 2 \mathrm{C} 12$ cultured cells, suggesting that GDF8 polymorphisms interact with transcription factors that are not muscle specific.

Furthermore, we could assess that the MYOD1-A allelic variant up-regulates the expression of MYOD1 gene in 
$\mathrm{C} 2 \mathrm{C} 12$ cells. The stronger activity of the A carrying construct was not statistically significant in $\mathrm{CHO}$ cells, suggesting a tissue-specific $M y o D$ activation in myoblasts.

\section{Additional files}

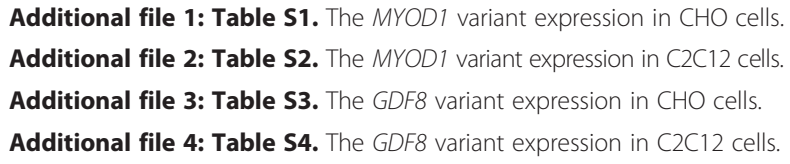

\section{Competing interests}

The authors declare that they have no competing interests.

\section{Authors' contributions}

SBo: designed the study, carried out sequencing and cloning experiments, and drafted the manuscript. SBi, MG: carried out sequencing experiments. FT, DW: realized transfection experiments. Fl: performed statistical analysis. MSD'A, FP: performed field survey and provided the samples. AV: participated in developing ideas, in supervision and revision of the manuscript. All authors read and approved the final manuscript.

\section{Acknowledgements}

This manuscript is dedicated to the memory of Lorraine Pariset. She was a brilliant scientist who is missed by all who knew her.

\section{Funding statement}

This research was supported by the GENZOOT research program, funded by Italian Ministry of Agriculture (MIPAAF).

\section{Author details}

${ }^{1}$ Department for Innovation in Biological, Agro-food and Forest systems, University of Tuscia, Viterbo 01100 , Italy. ${ }^{2}$ Department of Ecological and Biological Sciences, University of Tuscia, Viterbo 01100 , Italy. ${ }^{3}$ Department of Agricultural, Environmental and Food Sciences, University of Molise, Campobasso 86100, Italy.

Received: 20 June 2014 Accepted: 24 October 2014

Published online: 07 November 2014

\section{References}

1. te Pas MF, Soumillion A, Harders FL, Verburg FJ, van den Bosch TJ, Galesloot $\mathrm{P}$, Meuwissen $\mathrm{TH}$ : Influences of myogenin genotypes on birth weight, growth rate, carcass weight, backfat thickness, and lean weight of pigs. J Anim Sci 1999, 77(9):2352-2356.

2. Buckingham M: Skeletal muscle formation in vertebrates. Curr Opin Genet Dev 2001, 11(4):440-448

3. Urbański P, Kurył J: New SNPs in the coding and 5 ' flanking regions of porcine MYOD1 (MYF3) and MYF5 genes. J App/ Genet 2004, 45(3):325-329.

4. Gerber AN, Klesert TR, Bergstrom DA, Tapscott SJ: Two domains of MyoD mediate transcriptional activation of genes in repressive chromatin: a mechanism for lineage determination in myogenesis. Genes Dev 1997, 11(4):436-450.

5. Li L, Chambard JC, Karin M, Olson EN: Fos and Jun repress transcriptional activation by myogenin and MyoD: the amino terminus of Jun can mediate repression. Genes Dev 1992, 6(4):676-689.

6. Olson EN: MyoD family: a paradigm for development? Genes Dev 1990, 4(9):1454-1461.

7. Soumillion A, Rettenberger G, Vergouwe MN, Erkens JH, Lenstra JA, te Pas MF: Assignment of the porcine loci for MYOD1 to chromosome 2 and MYF5 to chromosome 5. Anim Genet 1997, 28(1):37-38.

8. Urbański P, Flisikowski K, Starzyński RR, Kurył J, Kamyczek M: A new SNP in the promoter region of the porcine MYF5 gene has no effect on its transcript level in m. longissimus dorsi. J App/ Genet 2006, 47(1):59-61.

9. Knoll A, Nebola M, Dvorák J, Cepica S: Detection of a Ddel PCR RFLP within intron 1 of the porcine MYOD1 (MYF3) locus. Anim Genet 1997, 28(4):321.
10. Lee EA, Kim JM, Lim KS, Ryu YC, Jeon WM, Hong KC: Effects of variation in porcine MYOD1 gene on muscle fiber characteristics, lean meat production, and meat quality traits. Meat Sci 2012, 92(1):36-43.

11. MCPherron $A C$, Lee $S$ J: Double muscling in cattle due to mutations in the myostatin gene. Proc Natl Acad Sci U S A 1997, 94(23):12457-12461.

12. Ji S, Losinski RL, Cornelius SG, Frank GR, Willis GM, Gerrard DE, Depreux FF, Spurlock ME: Myostatin expression in porcine tissues: tissue specificity and developmental and postnatal regulation. Am J Physiol 1998, 275(4 Pt 2):R1265-R1273.

13. Grobet $L$, Martin LJ, Poncelet D, Pirottin D, Brouwers B, Riquet J, Schoeberlein A, Dunner S, Ménissier F, Massabanda J, Fries R, Hanset R, Georges M: A deletion in the bovine myostatin gene causes the double-muscled phenotype in cattle. Nat Genet 1997, 17(1):71-74.

14. Kambadur R, Sharma M, Smith TP, Bass JJ: Mutations in myostatin (GDF8) in double-muscled Belgian Blue and Piedmontese cattle. Genome Res 1997, 7(9):910-916.

15. Grobet $L$, Poncelet $D$, Royo $L$, Brouwers B, Pirottin D, Michaux C, Ménissier F, Zanotti M, Dunner S, Georges M: Molecular definition of an allelic series of mutations disrupting the myostatin function and causing doublemuscling in cattle. Mamm Genome 1998, 9(3):210-213.

16. Marchitelli C, Savarese MC, Crisà A, Nardone A, Marsan PA, Valentini A: Double muscling in Marchigiana beef breed is caused by a stop codon in the third exon of myostatin gene. Mamm Genome 2003, 14(6):392-395.

17. Clop A, Marcq F, Takeda H, Pirottin D, Tordoir X, Bibé B, Bouix J, Caiment F, Elsen JM, Eychenne F, Larzul C, Laville E, Meish F, Milenkovic D, Tobin J, Charlier C, Georges M: A mutation creating a potential illegitimate microRNA target site in the myostatin gene affects muscularity in sheep. Nat Genet 2006, 38(7):813-818.

18. Szabó $G$, Dallmann $G$, Müller $G$, Patthy $L$, Soller M, Varga L: A deletion in the myostatin gene causes the compact ( $\mathrm{Cmpt}$ ) hypermuscular mutation in mice. Mamm Genome 1998, 9(8):671-672.

19. Mosher DS, Quignon P, Bustamante CD, Sutter NB, Mellersh CS, Parker HG, Ostrander EA: A mutation in the myostatin gene increases muscle mass and enhances racing performance in heterozygote dogs. PLoS Genet 2007, 3(5):e79.

20. McFarlane C, Hui GZ, Amanda WZ, Lau HY, Lokireddy S, Xiaojia G, Mouly V, Butler-Browne G, Gluckman PD, Sharma M, Kambadur R: Human myostatin negatively regulates human myoblast growth and differentiation. Am J Physiol Cell Physiol 2011, 301(1):C195-C203.

21. Schuelke M, Wagner KR, Stolz LE, Hübner C, Riebel T, Kömen W, Braun T, Tobin JF, Lee SJ: Myostatin mutation associated with gross muscle hypertrophy in a child. N Engl J Med 2004, 350(26):2682-2688.

22. Crisà A, Marchitelli C, Savarese MC, Valentini A: Sequence analysis of myostatin promoter in cattle. Cytogenet Genome Res 2003, 102(1-4):48-52.

23. Taketa Y, Nagai Y, Ogasawara H, Hayashi S, Miyake M, Tanaka S, Watanabe K, Ohwada S, Aso H, Yamaguchi T: Differential expression of myostatin and its receptor in the porcine anterior pituitary gland. Anim Sci J 2008, 79(3):382-390.

24. Stinckens A, Luyten T, Bijttebier J, Van den Maagdenberg K, Dieltiens D, Janssens S, De Smet S, Georges M, Buys N: Characterization of the complete porcine MSTN gene and expression levels in pig breeds differing in muscularity. Anim Genet 2008, 39(6):586-596.

25. Guimaraes SEF, Stahl CH, Lonergan SM, Geiger B, Rothschild MF: Myostatin promoter analysis and expression pattern in pigs. Livest Sci 2007, 112(1-2):143-150.

26. Stinckens A, Bijttebier J, Luyten T, Van Den Maagdenberg K, Harmegnies N, De Smet S, Georges M, Buys N: Detection of polymorphisms in the myostatin gene in Belgian Pietrain pigs. Commun Agric Appl Biol Sci 2005, 70(2):37-41.

27. Tu PA, Shiau JW, Ding ST, Lin EC, Wu MC, Wang PH: The association of genetic variations in the promoter region of myostatin gene with growth traits in Duroc pigs. Anim Biotechnol 2012, 23(4):291-298.

28. Burattini S, Ferri P, Battistelli M, Curci R, Luchetti F, Falcieri E: C2C12 murine myoblasts as a model of skeletal muscle development: morphofunctional characterization. Eur J Histochem 2004, 48(3):223-233.

29. Goldhamer DJ, Brunk BP, Faerman A, King A, Shani M, Emerson CP: Embryonic activation of the myoD gene is regulated by a highly conserved distal control element. Development 1995, 121(3):637-649.

30. Sdek P, Oyama K, Angelis E, Chan SS, Schenke-Layland K, MacLellan WR: Epigenetic regulation of myogenic gene expression by heterochromatin protein 1 alpha. PLoS One 2013, 8(3):e58319. 
31. Stratil A, Kopecný M: Genomic organization, sequence and polymorphism of the porcine myostatin (GDF8; MSTN) gene. Anim Genet 1999, 30(6):468-470.

32. Jiang YL, Li N, Plastow G, Liu ZL, Hu XX, Wu CX: Identification of three SNPs in the porcine myostatin gene (MSTN). Anim Biotechnol 2002, 13(1):173-178

33. Yu L, Tang H, Wang J, Wu Y, Zou L, Jiang Y, Wu C, Li N: Polymorphisms in the $5^{\prime}$ regulatory region of myostatin gene are associated with early growth traits in Yorkshire pigs. Sci China C Life Sci 2007, 50(5):642-647.

34. Liu D, Xu Q, Zang L, Liang S, Wu Y, Wei S, Jiang Y: Identification and genetic effect of haplotypes in the promoter region of porcine myostatin gene. Anim Genet 2011, 42(1):6-14.

35. Jiao J, Yuan T, Zhou Y, Xie W, Zhao Y, Zhao J, Ouyang H, Pang D: Analysis of myostatin and its related factors in various porcine tissues. J Anim Sci 2011, 89(10):3099-3106.

36. Ciarmela P, Wiater E, Smith SM, Vale W: Presence, actions, and regulation of myostatin in rat uterus and myometrial cells. Endocrinology 2009, 150(2):906-914.

37. Manickam R, Pena RN, Whitelaw CB: Mammary gland differentiation inversely correlates with GDF-8 expression. Mol Reprod Dev 2008, 75(12):1783-1788.

38. MCPherron AC, Lee SJ: Suppression of body fat accumulation in myostatin-deficient mice. J Clin Invest 2002, 109(5):595-601.

39. Mendias CL, Bakhurin Kl, Faulkner JA: Tendons of myostatin-deficient mice are small, brittle, and hypocellular. Proc Natl Acad Sci U S A 2008, 105(1):388-393.

40. Ríos R, Fernández-Nocelos S, Carneiro I, Arce VM, Devesa J: Differential response to exogenous and endogenous myostatin in myoblasts suggests that myostatin acts as an autocrine factor in vivo. Endocrinology 2004, 145(6):2795-2803.

41. Budasz-Świderska M, Jank M, Motyl T: Transforming growth factor- $\beta 1$ upregulates myostatin expression in mouse $\mathrm{C} 2 \mathrm{C} 12$ myoblasts. J Physiol Pharmacol 2005, 56(SUPPL. 3):195-214.

42. Deng B, Wen J, Ding Y, Gao Q, Huang H, Ran Z, Qian Y, Peng J, Jiang S: Functional analysis of pig myostatin gene promoter with some adipogenesis- and myogenesis-related factors. Mol Cell Biochem 2012, 363(1-2):291-299.

doi:10.1186/s12863-014-0119-2

Cite this article as: Bongiorni et al:: Promoter polymorphisms in genes involved in porcine myogenesis influence their transcriptional activity. BMC Genetics 2014 15:119.

\section{Submit your next manuscript to BioMed Central and take full advantage of:}

- Convenient online submission

- Thorough peer review

- No space constraints or color figure charges

- Immediate publication on acceptance

- Inclusion in PubMed, CAS, Scopus and Google Scholar

- Research which is freely available for redistribution 